\title{
forestry news
}

\section{People on the Move}

D. B. Turner has been appointed manager lumber and shingle (mainland) operations for the Wood Products Group of MacMillan Bloedell Ltd.

Malcolm F. Squires has been appointed chief forester for Price Nfld.

W. E. Jonas has been appointed Woods Manager of Churchill Forest Industries (Manitoba) Ltd.

Henry Clepper, for three decades Executive Director of the Society of American Foresters, on October 7 received the Distinguished Service Award of the American Forestry Association.

Dr. Clark: Dr. John Clark, recently retired research scientist with the Canadian Forestry Service for the past 21 years, and Mrs. Clark were feted recently in honor of Dr. Clark's retirement. A small group of $\mathrm{Dr}$. Clark's close Canadian Forestry Service associates in the Maritimes Region gathered at the home of Mr. and Mrs. Clark, 779 York Street. Gifts were formally presented to each of the married couple and reminiscences exchanged. $\mathrm{Dr}$. Clark's retirement was prompted by poor health.

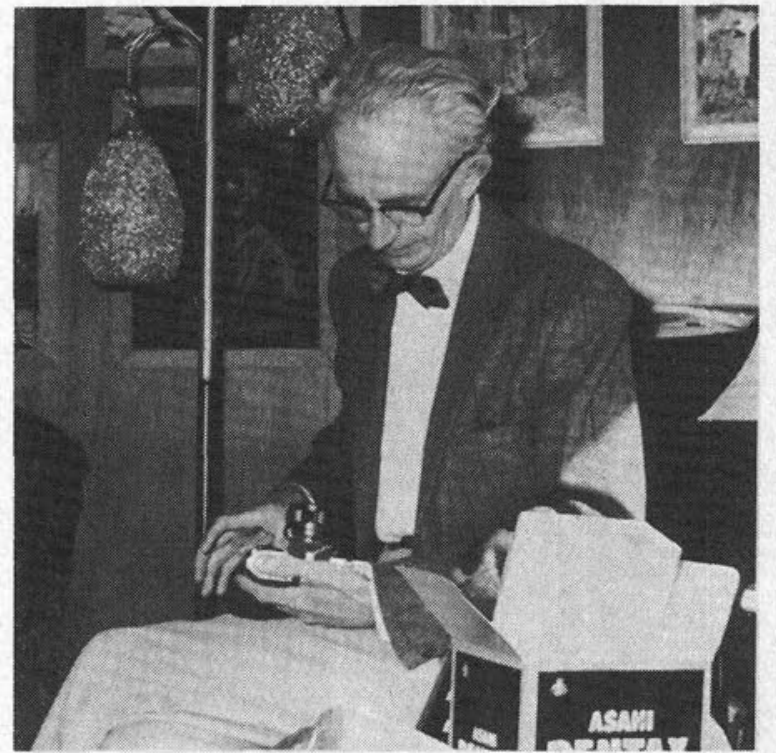

Dr. J. Clark

Dr. I. C. M. Place, Director of the Canadian Forestry Service's Maritimes Region, attended the IV General Assembly of the International Biological Program, September 25, to October 
2 in Rome, Italy. Associated with this meeting is an international symposium on the Ecological Bases of Environmental Management, and a working group meeting on the synthesis of productivity data from ecological studies in different parts of the world.

The International Biological Program (IBP) was started in 1967 at the instance of the International Council of Scientific Unions. Its main objectives are: (1) to determine the biological bases for production of food and fibre on land and in water, (2) to determine the potentialities and uses of new and existing natural resources, (3) preserve representative natural communities in danger of destruction and (4) to study human adaptability to changing conditions.

Dr. Place attended as one of the official Canadian delegates in his capacity as Chairman of the Canadian Sub-committee on Terrestrial Productivity. While in Europe, he also represented the $\mathrm{Ca}$ nadian Forestry Service at a meeting in Paris, October 14 to 16 , dealing with the control and certification of tree seed and plants moving in international trade. This latter meeting was held under the auspices of the Organization for Economic Cooperation and Development.

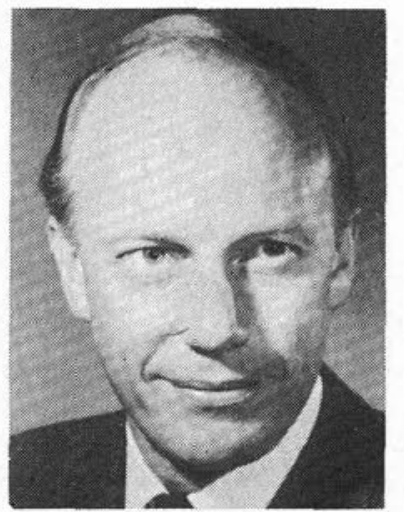

E. J. Ward

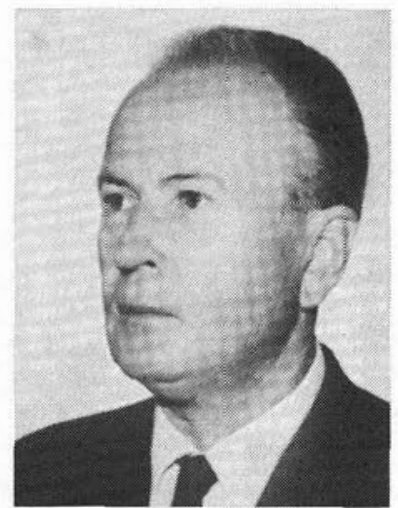

K. J. Roller
Dr. Kalman J. Roller has joined the Canadian Forestry Service Maritimes Region as a research scientist. $\mathrm{He}$ is a former director of the Forest Research Institute in Budapest, Hungary (1949-1953), and dean and professor of the Faculty of Forestry at the University of Sopron, Hungary (1953-1956).

Edward J. Ward, 40, has been appointed Wood Products Branch, Dept. Industry, Trade and Commerce, effective on July 29. He replaces T. C. Arnold who is now director of the Mechanical Transport Branch.

\section{B.C. Scaling}

Resources Minister Ray Williston has announced that all log scaling for government purposes in the province will soon be exclusively in firmwood cubic feet. The change-over will be complete by January 1,1972 , and will eliminate the present two competing units of measure - the board foot and lumber cubic scale.
The decision to drop the board foot scale in favour of cubic foot measurement was made following extensive study by a special committee appointed by Mr. Williston early this year. Its membership comprised representatives of the Forest Service, the Truck Loggers' Association, and the B.C. Council of Forest Industries.

Robert Corregan, scaling co-ordinator for the B.C. Forest Service, said the firmwood cubic scale is simpler in use thari the other forms of measurement, and provides a more accurate measure of wood volume.

The cubic foot scale is not new to British Columbia. It was introduced in 1953 and then withdrawn in favour of the compromise lumber cubic scale mainly because industry, at that time, regarded the change as too radical. Later it was re-introduced for use on tree farm licences, timber sales and other contracts which required close-utilization logging.

Board foot scaling remained in effect for timber from Crown-granted lands and various other forms of tenures, if the owners wished.

Over the years, explained Mr. Corregan, log scaling on the north coast, and in the interior, was conducted almost exclusively in cubic foot measurement. Throughout the Vancouver Forest District, however, with its large areas of Crown-granted lands, the board foot scale was retained. Considerable confusion and extra expense resulted from such a duplication of scales.

The board foot scale in B.C. dates back to the last century, and provided an estimate of lumber recovery from a log - in terms of sawmilling practices of that time. That form of scale has become increasingly irrelevant for sawlogs, and particularly for logs earmarked for pulp and veneer production.

The firmwood cubic scale provides the volume of sound wood in a log without relationship to any product which can be manufactured from it.

B.C. Forest Service

\section{Canada to Host Wood in Housing Conference}

The Government of Canada has invited 123 countries to send representatives to a WORLD CONSULTATION ON THE USE OF WOOD IN HOUSING to be held at the University of British Columbia, in Vancouver, July 5 to $16,1971$.

Co-sponsored by the United Nations Centre for Housing, Building and Planning, the United $\mathrm{Na}$ tions Industrial Development Organization, the Food and Agriculture Organization of the United Nations, and the International Union of Forestry Research Organizations, the CONSULTATION is expected to attract more than 500 persons.

Canada agreed to act as host for this international conference at the request of the co-sponsoring bodies. It was felt that Canadians, with their extensive use of the timber-frame method of house construction plus their considerable experience in the management of forestry resources and industries, could play a leading role at such a meeting. 
Particular emphasis will be given to problems of housing in developing countries. Discussions will cover such matters as housing needs, trends and prospects; forest inventories, growth potentials and accessibility; wood products and their use in construction; methods of alleviating fungus, insect attacks, fire hazards and other problems associated with the use of wood in construction; design, building techniques and costs; wood in housing in developing countries; and co-ordination of research and future developments.

D. R. Redmond, C.F.S.

\section{"Forestry Faculties}

\section{Need Help, Science Council Reports"}

"Lack staff, money and facilities"

Canada's four faculties of forestry are understaffed, underfinanced and their facilities are inadequate, the Science Council of Canada says.

A council report released yesterday in Ottawa on forest resources research proposes that the federal department responsible for forestry curtail its own research to provide more funds for research in the universities.

"Nothing short of a very substantial and sustained effort, to provide financial support for a minimum of 10 years to the forestry faculties through the federal department responsible for forestry, will raise the four university forestry faculties to the position of strength which the council considers essential if the solutions to Canadian problems are to emerge."

The demand for forestry graduates will increase steadily, and the need for graduates with resource development and environmental quality orientation will accelerate, says the report. Yet, notwithstanding some excellent staff in these areas and some research that has commanded international attention, the four faculties are short of staff, funds and facilities.

The research projects they choose as a result, are, in some cases, minor matters and the products of poverty. As a consequence forestry facilities do not attract their fair share of the really bright students.

"On the other hand, forestry activities at the federal level have been, by comparison, well funded. They have developed strength, and because of the disparate levels of funding between the federal laboratories and the universities, have developed a near monopoly in many of the areas of common interest.

"This whole system is circular because, as the university faculties get relatively weaker, the federal organization may claim quite justifiably the inadequacy of university research, and therefore (justify) more in-house research at the federal level.

"They may also complain about the quality and quantity of the graduates from Canadian universities and therefore may seek increasing numbers of their staff from outside Canada. This has a further negative impact on the universities."

"If the universities happen to recruit someone who is very good, the federal laboratories could hire him away on the basis of their superior equipment and funding. As the monopoly position increases, the federal agencies become inward-looking and their co-operation with universities becomes less."

The only way to break the circular process which now has reached a critical state - is for the federal forestry department deliberately and adequately to support the university forestry faculties, the council suggests. The $\$ 40,000$ annual grants made to each of the four faculty deans for the past several years are termed inadequate.

The facilities are at the University of Toronto, the University of New Brunswick, the University of British Columbia and Laval University.

Globe and Mail

\section{Harvard Research Fellowships}

Research Fellowships in Forest Resources are awarded annually by Harvard University from the Charles Bullard Fund. These Fellowships carry stipends up to $\$ 15,000$, the amount of each award depending on the professional status and needs of the recipient.

The purpose of this fellowship program is to support advanced research and study by men who show promise of making an important contribution, either as scholars or administrators, to forestry and forest management, these subjects to be defined in their broadest aspects - scientific, economic, political, administrative, and legal. Thus, the required qualifications for candidates and the research and study programs for fellowship recipients are written broadly. For further information, contact: Littauer Center 119, Harvard University, Cambridge, Mass. 02138, U.S.A.

\section{Canadian Weather Service Instruments Forestry Stations}

\section{in B.C.}

As part of a 10-year plan to expand the weather observing program in the less populated areas of the province, the Meteorological Branch of the Department of Transport has installed automatic recording equipment in a number of industry and Provincial Forest Service Stations.

B.C. Forest Service Ranger Stations at Horsefly, Valemount and Chetwynd were instrumented last April and two Bulkley Forest Industries Ltd. camps at McBride Lake and Goosly Lake were instrumented in October.

To be useful for climatological records weather observations must be recorded daily throughout the year. The installation of automatic recording in- 
struments such as the tipping bucket rain gauge and hygrothermograph make it possible to obtain an unbroken sequence of readings even when the observer is absent for short periods of time, as on holidays or weekends.

These cooperative stations not only augment the basic climatological network, but in the summer months they also provide supplemental observations for the fire weather forecasting unit of the Vancouver Weather Office.

Weather data from the Bulkley Valley Forest Industries Ltd. stations will be particularly useful in studying the orographic effect of the coastal mountains on the precipitation patterns associated with Pacific storms.

As data becomes available they will be summarized and published by the Meteorological Branch in the "Monthly Record" of meteorological observations in Canada.

S. Nikleva

\section{Ontario Department of Lands and Forests Reorganizes}

On November 13, 1970, the Hon. Rene Brunelle announced a major reorganization to commence April 1, 1971.

The announcement follows two years of intensive effort by the Department to improve its capability in the areas of decentralization of service to the public, decision making, long range planning, and coordination of functions. An internal study revealed major problem areas in the Deputy Minister's span of control and in the degree to which decision making is decentralized. It should be emphasized that the Department is recognized for its decentralized form of administration at present but the study recommended an even greater delegation of authority to its field staff. The former span of control of the Deputy Minister included fifteen positions. The new organization reduces this to eight. This is made up of four executive directors, three regional directors, plus the director of Research.

Each executive director is responsible for one of four major head office divisions.

The four new division and respective directors are:

Division of Administration

Division of Land Management

R. R. MacBean

Division of Outdoor Recreation J. W. Giles

to be named

Division of Resource Development A. J. Herridge

$\mathrm{Mr}$. Herridge is former Chief, Timber Branch, Mr. MacBean is former Chief, Accounts Branch and Mr. Giles previously held the title of Director, Southern Region.

The three regional directors are:

Northwestern Region

Northeastern Region

L. Ringham

Southern Region
Mr. Lockwood and Mr. Ringham held regional director positions prior to reorganization. Mr. Carman was formerly Planning Analyst for the Deputy Minister.

Dr. W. R. Henson will continue as Director of the Research Branch.

Mr. G. H. U. Bayly, Deputy Minister, the regional directors and the executive directors will comprise the senior management committee with the responsibility for planning and coordinating all activities of the Department. With this approach the regional directors become part of Head Office for the policy development and strategic planning functions.

The structure of the divisions in head office is designed to focus attention on the objectives of the Department. Each division is related to a public service objective with the exception of Administration which is designed to provide support services to the whole Department. This approach will highlight the Head Office role in the long-range strategic planning area and will focus attention on specific needs of the public rather than on the specific natural resources.

The Division of Land Management is concerned with the management of land and water resources both as a habitat for man and as the base for a wide variety of uses. The scope of responsibility includes the allocation and control of land and water use, environmental protection and inter-agency cooperation in land management. The Division of Outdoor Recreation will be concerned with meeting man's psychological and physical needs associated with leisure and with the economic impact of tourism. The scope of responsibility includes providing opportunities for a wide variety of outdoor recreational experiences. The Division of Resource Development is concerned with the contribution to the economy of Ontario which are made by industries utilizing renewable natural resources. The scope of responsibility includes growing crops and assisting industry in the areas of commercial fish, fur and timber.

The regional directors will be responsible for achieving coordination and integration of field activities. In addition, they will become more directly involved in the line management of the Department. The district foresters will continue to be responsible for integration and coordination at the district level and will become increasingly responsible for the accomplishment of the operational work of the Department.

\section{Lakehead Invites Woodsmen to Compete}

Lakehead University Forestry Association is holding an International Woodsman's Competition on January 16, 1971. Invitations have been sent out to every university offering a forestry program across Canada and the United States and we hope that there will be a large attendance and some extremely keen competition.

As the event coincides with our University Winter Carnival we can promise a Forester's Ball, a 
dinner and much, much more. Accommodation and meals will be provided.

Six-man teams will compete in the following events: Dot splitting, Bucksawing, Cross-cut sawing, Pulp throwing, Water boiling, Axe throwing, Chain sawing, Felling and twitching, Chopping and splitting.

There will also be a snowshoe race over 1 mile on the campus.

The competition entry fee is $\$ 30.00$ and entries close on December 15, 1970. Replies should be forwarded by November 15, 1970, to Lakehead University Forestry Association with cheques payable to the same.

\section{The Bucket Brigade}

Today's bucket brigade makes use of plastic pails holding as much as 1,000 gallons of water and carried to the fire from the nearest river, ocean, lake, pond or reservoir by helicopter. The technique has been successful against timber fires in the Pacific Northwest and brushland fires in the south central United States. But it was in Vietnam that the flying bucket brigade demonstrated the quenching of structural fires.

The U.S. Army, at the request of the Forest Service, tested new models of the flying bucket both for aerodynamic qualities and fire-fighting effectiveness.

The Vietnam fires have been fought with 450 gallon buckets-one pair per helicopter. Now a new 1,000 -gallon bucket is available and was "flighttested" last January at Edwards Air Force Base, California. Manufactured by Sims Fiberglass Company of Jefferson, Oregon, the new bucket was checked for flight stability. Trap doors in the bottoms of the fiberglass buckets are opened and closed remotely by a member of the helicopter crew.

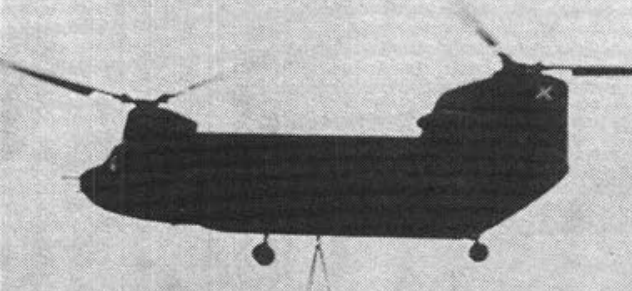

The 1,000-gallon model weighs 8,900 pounds full of water. That is a lot of weight to be swinging at the end of a cable. If it should flutter or undulate, the aircraft might be imperiled. According to Boeing representative the tests at Edwards determined the "flight envelope" in which the bucket should be used safely.
Forest Service representatives measured resulting water patterns and densities. During the $81 / 2$ to 11 seconds it took to empty the big bucket, the helicopter pilot sensed only a slight acceleration of his aircraft.

Boeing $40(7), 1970$

\section{The Canadian Journal of Forest Research}

A new publication beginning in 1971

In 1971 the National Research Council of Canada will begin the publication of a new international journal, the Canadian Journal of Forest Research. It will publish, in English or in French, reports of original scientific research as articles or notes, and acceptable discussions of them. All aspects of forestry science will be covered, and interdisciplinary papers will be especially welcome. The page format will be $7 \frac{1}{2} \times 10$ inches $(19 \times 25 \mathrm{~cm})$ with two columns. The journal will be issued quarterly beginning in March. Manuscripts should be sent to the editor, Dr. J. L. Farrar, Faculty of Forestry, University of Toronto, Toronto 5, Ontario. Annual subscription rates, in Canadian funds, are: multi-user, $\$ 10.00$; personal, $\$ 5.00$. Subscriptions should be sent to Administration, National Research Council of Canada, Ottawa 7, Canada, with remittances made payable to the Receiver General of Canada.

\section{Canada-Ontario Forest Research}

At the Fourth Meeting of the Canada-Ontario Forest Research Advisory Committee it was agreed that steps should be taken to familiarize practising foresters in the Province with the operation of the Joint Committee and to indicate to what extent the research groups are attempting to meet the needs of forest management in Ontario.

The Committee meets three or four times a year for sessions of one and a half to two days. The meetings held since the reconstruction of the Committee, approximately a year and a half ago, have been directed toward clarifying the role of the Committee and the preparation of statements indicating on the one hand the needs of forest management as seen by the Ontario Department of Lands and Forests and the research programs to be undertaken by both the Ontario Department and the Canadian Forestry Service towards the solution of these problems.

The following excerpts from the Memoranda of Agreement between the two Departments point up the essential features of their working relationships:

"To ensure the fullest and most efficient and effective use possible of the forest research resources available in the Ontario Region establishment of the 
Canadian Forestry Service of the Department of Fisheries and Forestry and in the Research Branch of the Ontario Department of Lands and Forests.

The following terms of reference stated for the Committee are:

(a) To co-ordinate the planning of forestry research programs of the Ontario Regional Establishment of the Department of Forestry and Rural Development and the Research Branch of the Ontario Department of Lands and Forests, by reviewing the needs of forest management in the Province of Ontario and by recommending appropriate research programs to be undertaken by the two research organizations.

(b) To co-ordinate the execution of forestry research programs of the two research organizations by reviewing the progress of approved programs and by facilitating their conduct.

It is recognized that some of the management problems in Ontario can best be solved within a broader national context and therefore a portion of the effort of the federal research group will be devoted to the solution of such problems within nationally planned research programs. This effort will, however, in no way diminish the direction of their program toward the solution of important Ontario forest management problems".

The Committee feels that the thinking with respect to research and management should be communicated to the practising foresters. A list of approved projects presently being carried out by the Ontario Region, Canadian Forestry Service and the Research Branch of Lands and Forests is available from either department.

\section{Ont. Dept. Lands \& Forests}

\section{Prescribed Burning in the Southeastern Coastal Plains:}

Will the explosive but justified emphasis on quality of the environment place the practice of prescribed burning under attack? If this happens, will we be able to provide the answers to questions that are bound to be raised?

What are its effects on vegetation, timber species, and wildlife and range habitats?

... How does it affect physical and chemical properties, long-term productivity, and the microbial and faunal populations of soils?

What is the impact on aesthetic and recreational values-the landscape, outdoor recreation, tourism? ... What are the broad environmental aspects of prescribed burning?

... Does it contribute to air pollution?

... Will public pressures and legislative or legal actions curtail or restrict its use?

... What alternative practices are available to land managers?
...What is the ecologist's view of prescribed burning and its impact on the ecosystem?

To help find answers to these and other questions, the Southeastern Forest Experiment Station, in cooperation with the Belle W. Baruch Research Institute, Clemson University, and Duke University, will sponsor a symposium on prescribed burning April 14-16, 1971, in Charleston, S.C.

U.S.D.A.F.S.

\section{Forest Insect and Disease Conference}

A record number of delegates attended the 1970 Central International Forest Insect and Disease Conference held in Sault Ste. Marie in late September.

More than 100 visiting scientists from the provinces of Manitoba, Ontario, Quebec and the states of Minnesota, Wisconsin, Michigan, Ohio and Missouri and from Washington, D.C. registered for the two-day event. This year's theme was "New approaches to forest pest management".

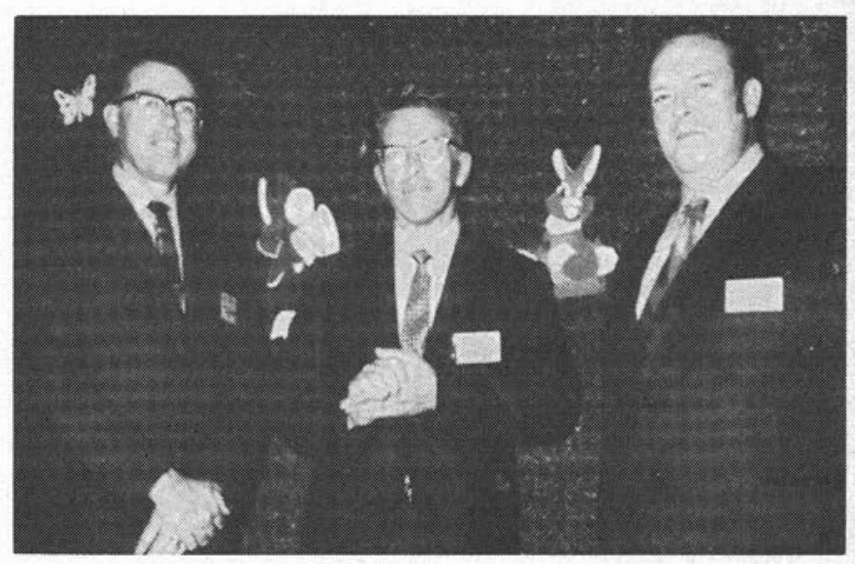

Three delegates to the 19th annual Central International Forest Insect and Disease Conference held in Sault Ste. Marie, Ontario are shown (left to right) Dr. Robert Patton, University of Wisconsin; conference chairman Dr. W. L. Sippell, Canadian Forestry Service and Dr. Marcel Lortie, Regional Director, Quebec Region of the Canadian Forestry Service. (CFS photo)

This annual conference provides forest entomologists and pathologists in central North America with an opportunity to exchange information on insect and disease problems of common interest. The host organization this year was the Forest Research Laboratory of the Canadian Forestry Service in Sault Ste. Marie. Dr. W. L. Sippell, who is responsible for the Forest Insect and Disease Survey of this laboratory, acted as conference chairman.

After reviewing background information on the most important current problems of central Canada and north central U.S.A., entomologists and pathologists discussed various promising new approaches to insect and disease control. Some of these included the release of parasites, the use of insect viruses and sex hormones and the application of epicentre knockout spraying against insect pests. In separate sessions the pathologists dealt with important root rots such as Fomes annosus, the question as to whether or not the disease organism 
Scleroderris is indigenous to North America, the breeding of resistant elms and the integrated approach of the Sault Laboratories toward the problem of controlling Dutch elm disease.

On a field trip north of the city, delegates viewed various insect and disease conditions including a combined insect and disease problem of yellow birch. Following this, delegates were given an explanation of the techniques used in virus multiplication at the Insect Pathology Research Institute and a description of the City of Sault Ste. Marie's Dutch elm disease sanitation-management program.

The meeting concluded with the decision to hold the 1971 conference at the University of Wisconsin.

C.F.S. Sault Ste. Marie

\section{Science Council Reports on}

\section{Forest and Wildlife Research}

The Science Council of Canada has produced Report No. 8 "Seeing the Forest and the Trees", 1970, $19 \mathrm{pp}$. This report "relies heavily on the results of Special Study No. 14, Forest Resources Research in Canada by Dr. J. H. G. Smith and Mr. J. L. G. Lessard". It highlights the results of the study and makes recommendations (15 in total) for action.

Report No. 9 "This Land is their Land," 37 pp., of the Science Council reports on fisheries and wildlife research in Canada. This report gives high priority to the formation of an Environmental Council of Canada.

Both reports are available for 75 cents each from the Queens Printer, Ottawa and Canadian Government bookshops. Catalogue Nos. SS22-1970/8 and SS22-1970/9.

\section{The 2, 4, 5 - T Ban}

Opinions on "the ban of 2, 4, 5-T and its implications" were voiced at the Annual Meeting of the Canada Weed Committee, Eastern Section, in Montreal, November 5. The Canada Weed Committee, Eastern Section, in Montreal, November 5.) The Canada Weed Committee was never consulted prior to banning the use of 2, 4, 5-T on food crops and restricting its use from house, garden, and recreation areas. (An exception is made in the case of poison ivy control on recreation areas where 2, $4,5-T$ can be used if the area is properly posted.)

Problems with 2, 4, 5- T in the Vietnam area were widely publicized, and became a local issue when 2, 4, 5 - $\mathrm{T}$ was used to control brush along the U.S./Canada border a year ago. It developed into a major concern when it was shown that pregnant rats fed high dosages of 2, 4, 5 - T produced abnormal offspring. This latter evidence was finally discredited when it was shown that the original sample of 2, 4, 5 - T was contaminated with dioxin.

The U.S. ban of 2, 4, 5 - T was hastily copied by Canadian politicians, even though dioxin had been identified as the real culprit. All technical grades of $2,4,5-T$ contain some dioxin ranging as high as
22 parts per million. The problem is to establish a safe level of dioxin contamination which may be of the order of 0.5 parts per million.

The Food and Drug Directorate can find no evidence of residues of 2, 4, $5-\mathrm{T}$ on food crops. They believe that if 2, 4, 5 - T can be manufactured pure, then it may be reinstated for use on agricultural food crops, although probably not about homes and recreation areas. It seems that 2, 4, $5-\mathrm{T}$ may be used safely in various forestry applications provided the chemical manufacturer will guarantee delivery of a pure product.

\section{Quebec Council On Environment}

A new organization aimed at combating pollution and achieving environmental quality control held its founding congress November 7, 1970 at the Montreal Botanical Garden.

Called the Conseil Québécois de I'Environnement (Quebec Council on Environment) its membership includes industrial and business firms, associations with a particular interest in outdoor activity and environment, and individuals.

\section{Other groups out}

The council was to include existing anti-pollution groups such as the Society To Overcome Pollution, La Société pour Vaincre la Pollution, and Le mouvement de résistance à la pollution. The Quebec Wildlife Federation was also to have been included.

However, leaders of these groups expressed dissatisfaction with what has apparently been communication between the council and their groups and boycotted the congress.

Organizers of the council said they intended to create a fully representative group and present a united front in the fight for a better environment.

Dr. L. Z. Rousseau, president of the council, said it was hoped to assess regional problems, take advantage of the strong points of various anti-pollution groups and act as a strong pressure organization.

"We want to offer positive suggestions to government and make a constructive contribution," he said. "We do not intend to be a tool of government nor do we intend to get into the game of creating political footballs."

Professor Michel Maldague, of the Faculty of Forestry and Geodesy at Laval University, delivered the main address at the congress in which he spelled out the objectives of the council.

The CEQ plans to embark on a comprehensive program of education and information aimed at arousing public interest and involvement.

Another goal will be to safeguard wildlife and its natural habitat in all parts of Quebec. Special attention would be directed to preserving threatened species.

Action will be taken on a program of scientific 
research and the sharing of knowledge about the latest techniques in environmental quality control.

A detailed environmental chart will be drawn up to serve as a basis for the regulated use of natural resources as well as for a regulated improvement of the total environment.

The council will also strive for the rehabilitation of historical sites and other areas of cultural or anthropological significance.

Dr. Victor Goldbloom, the provincial minister responsible for environmental matters, had earlier indicated government would listen to constructive recommendations.

Montreal Star.

\section{Ontario Folding Fire Bombing Tank (Model H-75)}

A new design in fire bombing equipment has been developed by the Air Service Section of the Ontario Department of Lands and Forests ir, Sault Ste. Marie, Ontario.

The first in a series of the "Ontario Folding Fire Bombing Tank" was designed for the Bell 47G-4 helicopter and has been designated as a Model $\mathrm{H}-75$.

The tank is constructed with aluminum metal frames and water-proof fabric which allows the tank to be retracted and folded automatically when not in use. The control system is all electric and automatic with emergency manual back-up systems. The dumping system is retractable "SOCK" which provides an opening one foot wide and three feet long for discharging the 75-gallon load of water or

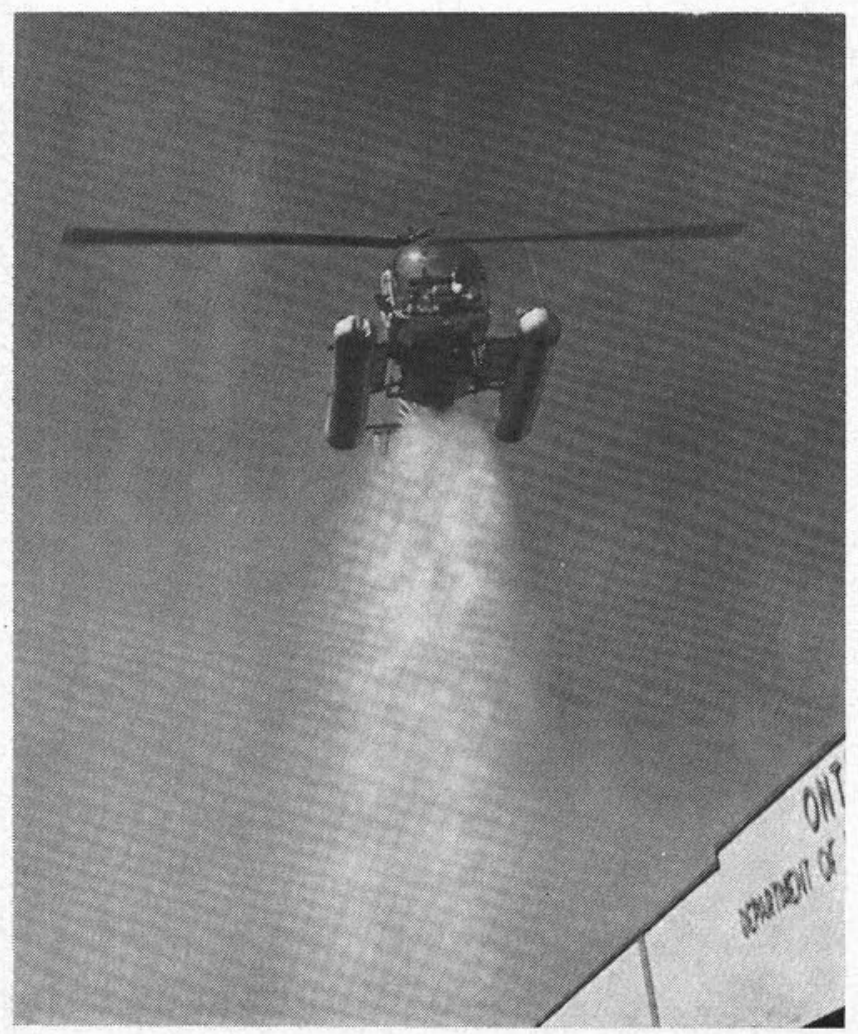

chemicals. The tank is filled with water by twin electric pumps at the rate of one gallon per second.

The pilot's control panel provides him with two options: first, a load selector permits him to pick up the required load; the water load is increased as fuel is consumed to keep the helicopter at maximum permissible gross weight. Second, a drop pattern selector changes the size of the opening varying the rate of discharge. Once these two selections are made, the pilot's operation of the system consists of pushing the bomb button to dump the load, the rest is automatic.

By varying the airspeed of the helicopter, the drop pattern will vary from 15 feet in length to 500 feet in length providing the most versatile fire-bombing system in helicopters to date.

The helicopter has an advantage over the fixed wing aircraft in fire-bombing. Helicopters are more accurate because of their ability to bomb at very low speeds and their ability to pick up water loads from small ponds and streams; the fixed wing aircraft requires a much larger body of water and usually must travel much farther from the fire to pick up a load of water.

T. C. Cooke, Ont. Dept. Lands and Forests

\section{Peat Drainage}

Two extensive Russian publications dealing with tree growth on wet lands and the drainage of peat have recently been privately translated by J. K. McEwen, Research Scientist with the Ontario Department of Lands and Forests at Thunder Bay, Ontario. The two publications are: "The Influence of Excess Soil Moisture on Forest Productivity", edited by A. A. Molchanov Academy of Science, U.S.S.R. Silvicultural Laboratory, Moscow, 1966, and "Mire Forests and Their Improvement" by L. P. Smolyak, Academy of Science of the White Russian S.S.R., Institute of Experimental Botany, 1969. These two publications summarize the very extensive work that has been done in Russia in this field of specialization.

\section{G. Weetman}

\section{Tree Seed Certification}

Canada's entry into the international Organization for Economic Cooperation and Development (OECD) allows forest tree seed exporters in British Columbia to have their material certified and eligible for sale in foreign countries, said the Canadian Forestry Service in Victoria.

In 1967, OECD established a scheme for control of forest reproductive material moving in international trade. The chief objective was to encourage production and use of forest seeds and other reproductive material in such a way that the buyer received authentic information about the source and origin of the material sold.

Dr. G. P. Thomas, Canadian Forestry Service Regional Director for B.C., named to administer the scheme in this area, said that although Canada was active in formulating the principles of the plan, "we 
have not participated in its actual operation. Our present application," he added, "is a result of a number of European countries, including a few that import forest tree seed in commercial quantities from British Columbia, insisting that forest reproductive material will no longer be allowed to be imported unless certified under the OECD scheme."

Seed export companies concerned about the possible loss of overseas markets urged the federal government to adopt the OECD plan in British Columbia. As a result, the Canadian Forestry Service agreed to make its services available in B.C. After consultation with the British Columbia Forest Service, the appropriate application was submitted and action was taken to enable certification of collections from the 1970 seed crop. Exporters are presently collecting and processing material in accordance with the rules laid down by OECD and the requirements of the Canadian Forestry Service.

Only source identification of tree seed will be provided this year. There is no immediate demand for certification of other categories of forest reproductive material.

$\mathrm{Dr}$. Thomas said that certification must be effected before the seed is exported. This means that extraction of seeds from cones must be done in Canada.

Participation by exporting companies is voluntary. Companies will be required to provide detailed information as to the name of the collector and location of collection, processing and storage. Export certificates will be issued after the Canadian Forestry Service is satisfied that OECD regulations have been met.

Additional information on this scheme is available from the Director, Forest Research Laboratory, 506 West Burnside Road, Victoria, B.C.

CFS Release

\section{Reservoir Salvage in B.C.}

When the Aluminum Company of Canada built the Kenney Dam on the Nechako River in 1952, it raised the water level behind the damsite as much as 317 feet, and flooded several mountain valleys. It wrought great geographical changes over the 5,500 square mile drainage area of the Nechako and created a 358 square mile reservoir - or chain of reservoirs. The rising waters covered great expenses of forest land containing prime stands of spruce, lodgepole pine and some hemlock. Some trees were completely covered but tens of thousands still show their heads above the waters of Ootsa, Whitesail, Tahtsa and Tatachuk Lakes. Total length of the newly created shoreline is about 1,000 miles and most of it is dotted with tree tops. The tops are rotten and of no value but beneath the lake surface the timber is as sound and as well preserved as when the waters first rose.

The Bond Brothers with their own funds and their inventive skills, designed a self-propelled steel barge equipped to nip off standing trees at the buttend as much as 120 feet below the lake surface. Only two men are required to work all the equip-

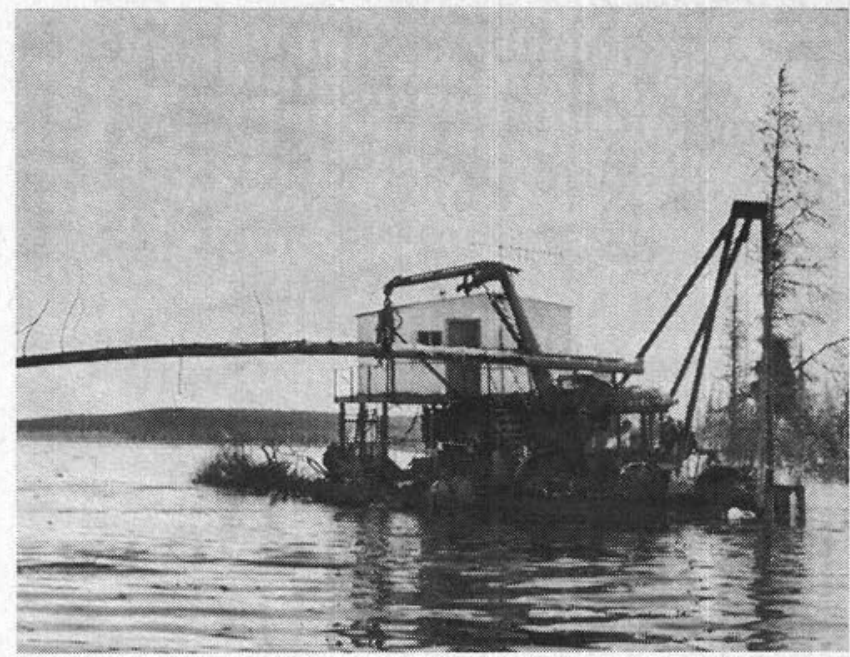

ment on the barge while a third operates a small boom boat which tows the bundled logs to a nearby booming ground.

The barge can be moved in any direction by a single fully rotating propeller located on the bottom of the hull. As the floating logging camp approaches a tree-top, a three-ton grapling device suspended over the bow by a cable from a heavy steel stanchion encircles the trunk. An operator then lowers the heavy contrivance to the bottom of the tree on the lake bed by paying out cable from a drum located amidships. During this action the branches of the tree are broken off leaving a relatively clean trunk.

B.C. Forest Service

\section{I.U.F.R.O. Meets to Reorganize}

The general aim of I.U.F.R.O. is to coordinate, and to originate research on an international basis, to bring people together on the same problems, and to arrange regular meetings. Joint committees have been set up together with the F.A.O. on bibliography, forest education, forest improvement, and international seed control. I.U.F.R.O. has been constituted into several sections concerned with forest influences, protection, growth and yield, management, economics, silvics, silviculture, genetics, amelioration, work studies, forest products, statistics, recreation and wildlife, wood technology, operational efficiency, etc.

Section 23 "Technical Means for Amelioration of Forest Production (Silviculture)" met in Ljubljana, Yugoslavia from September 30 to October 7 to discuss organizational matters in preparation of the 15th I.U.F.R.O. congress to be held at the University of Florida at Gainesville, Florida, U.S.A., during the period of March 14-20, 1971. This congress, the first to be organized outside of Europe, is going to be very important, because of the influence expected from the North American participants on its future goals and organizational structure.

All sessions of section 23 were held in the biotechnical faculty at Ljubljana. The participants were welcomed by the Yugoslav organizers, by members of the Yugoslav government, by the Dean of the Biotechnical Faculty, and Prof. Dr. M. Van Miegroet, 
Belgium, the present President of Section 23. It was understood that proposals will be made concerning the reorganization of I.U.F.R.O. to suit the increased international scope and to make provisions for the research objectives specific to the North American Continent.

The congress in Florida should lay the foundation for a "dimension nouvelle", i.e., new paths which the international research could follow together. A good thorough planning of the congress in Florida is important because it will give an opportunity to demonstrate the forestry development in five continents, it should permit open exchange of ideas, seek solution to common problems, define international research aims of the future, and enhance the development of good personal relations.

In Florida, the present structure of I.U.F.R.O. will most likely be abolished to make way for six new Divisions:

(1)Forest Botany, Genetics and Plant Protection;

(2) Silviculture, Site, Ecology, Productivity;

(3) Economics and Forest Policy;

(4) Utilization;

(5) Operation and Technology, Mechanization;

(6) General Matters, Terminology, Recreation, Biometrics, Statistics.

The present section 23 would come under Division (2) which in turn will be subdivided into two parts. Part I, consisting of five permanent subject groups: Study of the Forest as an Ecosystem, Establishment and Treatment of Strands, Tropical Silviculture, Site Studies, Study of Production, and Part II consisting of temporary project groups which could be composed of members from different divisions. The project groups could be created according to need and requirement dictated by specific problems.

Presently section 23 has approximately 550 regularly corresponding active members. It is expected that the membership will be increased, particularly by researchers from the North American Continent, Australia, New Zealand and Japan. Russian participation is not frequent, but could increase in future.

The budget of I.U.F.R.O., as always, has been, very limited. Financing is from membership fees of 120 Swiss francs per year, or approximately $\$ 35.00$ Canadian, paid by each institution. A great deal of the costs are carried by the country hosting a congress. In spite of these limitations, annual and other reports are issued.

During the plenary sessions in Ljubljana, several highly interesting papers centered around the increasing emphasis on management in forestry at the cost of silviculture and of silvicultural research. It was noted that increased efficiency, technical progress and profitability of forest operations require a re-orientation of silviculture as a science and updating of techniques for the dissemination of results.

The three day sessions concluded with an impressive art exhibition in Ljubljana under the theme "forest, wood and the creative arts", and several study tours in Slovenia, the northern part of Yugoslavia.

The participants left with the impression that the 15 th congress at Gainesville will provide an excellent forum for improved international cooperation in the field of forestry.

\author{
Walter Stanek, \\ Forest Research Laboratory, \\ Sault Ste. Marie, Ontario.
}

\section{Nova Scotia Section}

\section{Awards Bursary}

F. V. Clark of Truro, N.S., Chairman of the Nova Scotia Section, Canadian Institute of Forestry, has announced that Maxwell R. Tanner, Forestry Student at the University of New Brunswick, has been chosen as the recipient of a $\$ 100.00$ bursary granted annually by the Section.

Mr. Tanner is the son of Mr. and Mrs. Robert Tanner, R.R. \#3, Bridgewater, N.S. and is presently entered at U.N.B. as a fourth year student in a five year course leading toward a degree in Forestry.

Through the cooperation of the U.N.B. Faculty of Forestry, the N.S. Section began the bursary programme in 1966 toward assisting a worthy fourth year student coming from the Province of Nova Scotia. Previous recipients were D. A. MacGregor, New Glasgow in 1966; F. J. Delorey, Tracadie in 1967; G. F. Elliott, Bridgewater in 1968; and D. G. Alaffe, Stellarton in 1969.

\section{Dryden High School Conservation Course}

The Dryden Conservation Camp was first conceived in 1956 by T. S. Jones presently Vice President and Divisional Manager, Dryden Paper Company, who visualized the need for a practical program to develop an informal and responsible public awareness of the needs and benefits of proper use and care of our natural resources. The president of the Company approved the idea and the Dryden High School Board accepted with enthusiasm the offer made by the Company to sponsor the camp. After investigating the Trees for Tomorrow Camp at Eagle River, Wisconsin, a three day field course was set up. The first camp begain in 1957 and has continued on an annual basis to the present.

\section{The Objectives of the camp program are:}

(1) To add to the students understanding of the concepts on which resource management is based.

(2) To emphasize that the renewable resources - soil, forests, water and wildlife are inter-related and inter-dependent.

(3) To emphasize that the purpose of resource management is to benefit people.

(4) To present conservation concepts in their natural setting. 


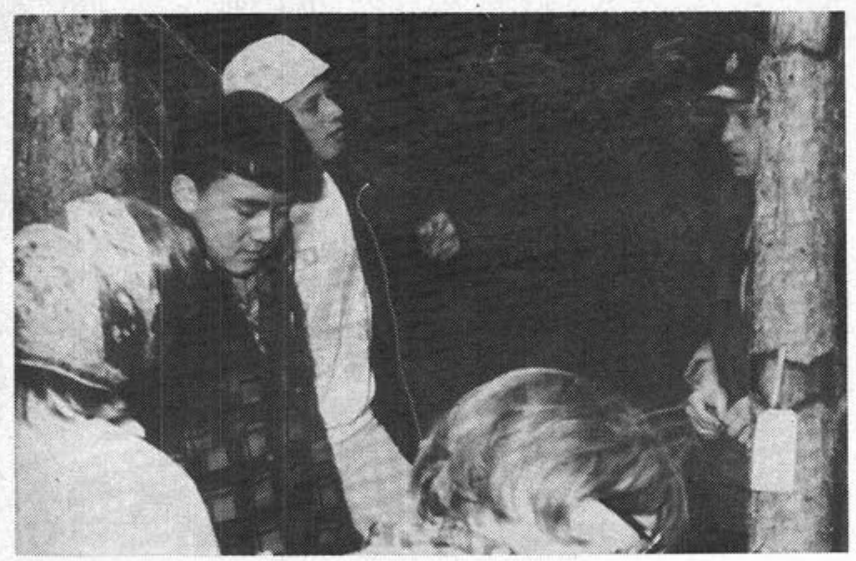

Students calculating a local stream flow.

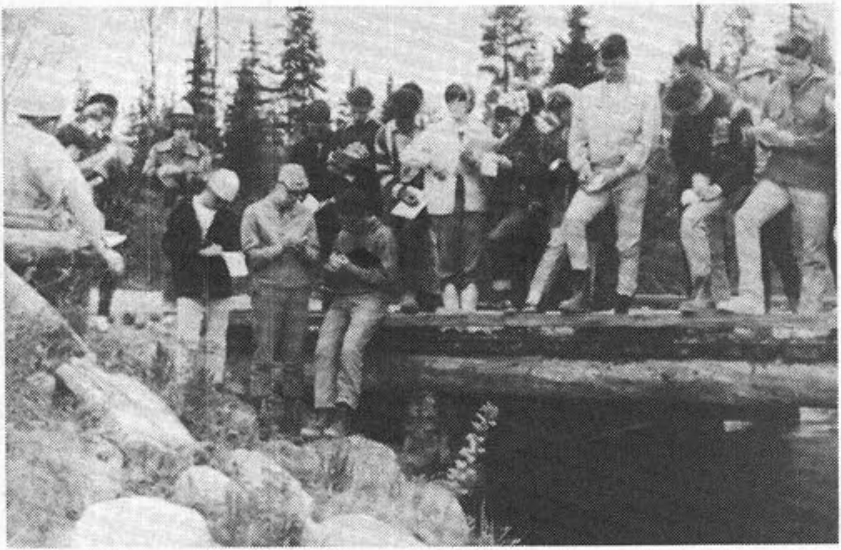

Nature trail, examining animal damage to tree.

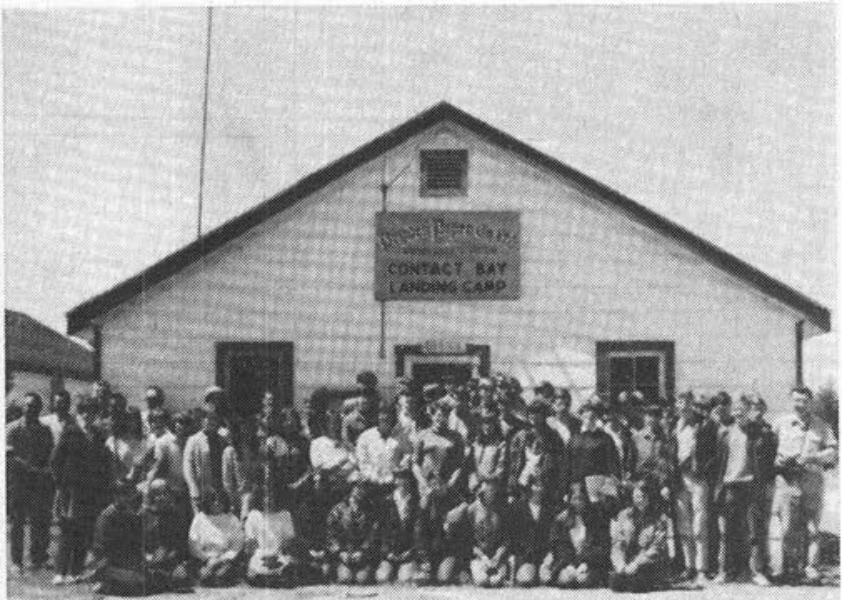

Group picture at contact Bay Camp.

(5) To encourage a liking for conservation knowledge and suggest ways of continuing the study of resource development.

The camp has been designed for the Grade $X$ level because the camp advisory committee felt these students are best equipped to understand, retain and implement the conservation concepts presented.

The advisory committee consisting of company personnel, the local district forester, the local agricultural representative and the principal of the Dryden High School meet in the early spring of each year to organize and plan the current course.

The instructors, specialists in their field, have

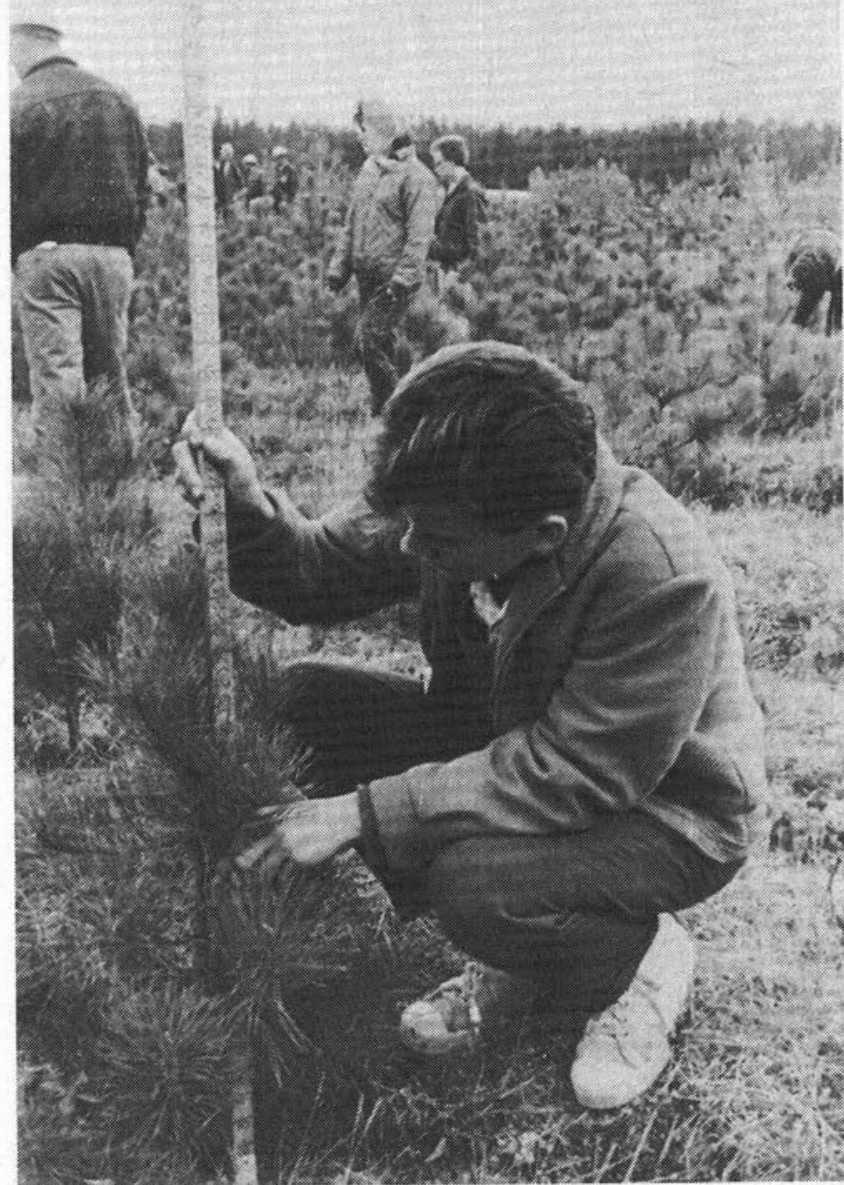

Red pine provenance test: students conducting an assessment test.

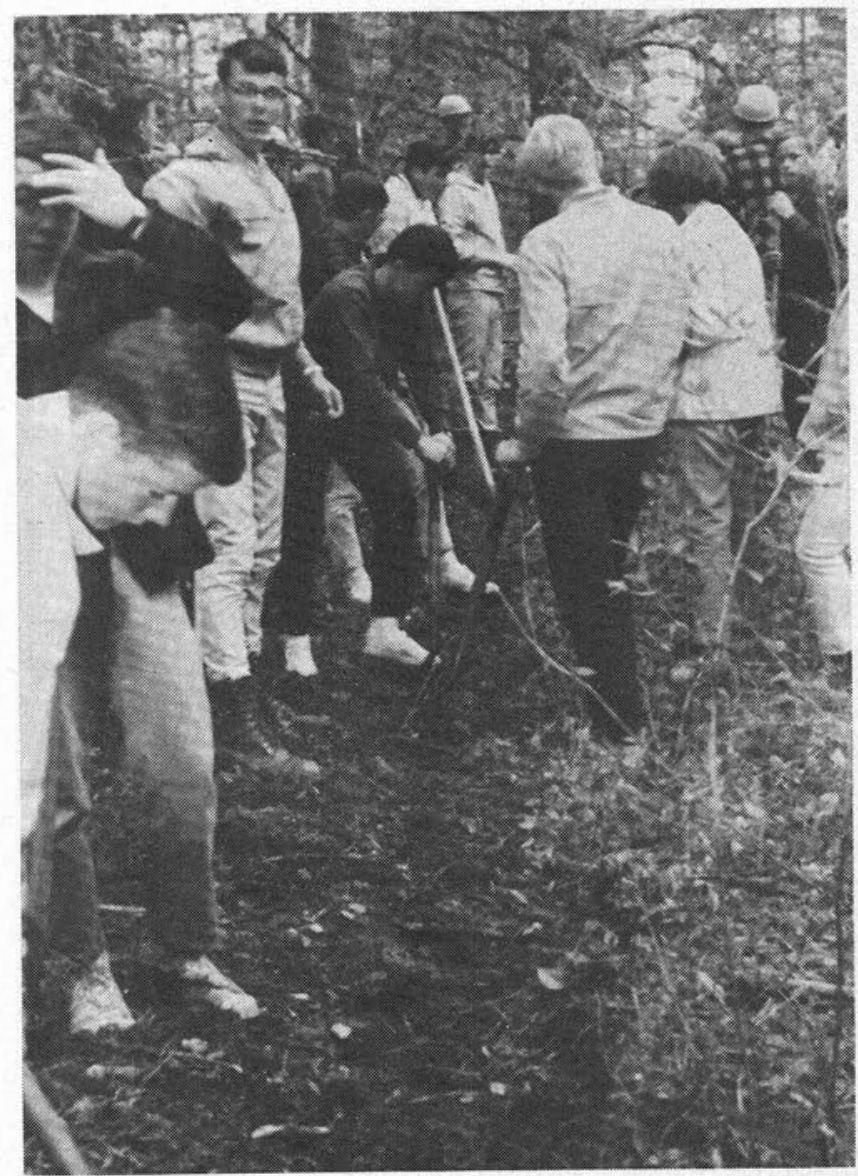

Students building a fire break with hand tools.

December 1970 The Forestry Chronicle 
been made available by the Ontario Forestry Association, the Ontario Department of Lands and Forests, the Ontario Hydro Electric Power Commission, the Federal Department of Fisheries and Forestry, the Ontario Department of Agriculture, the Ontario Water Resources Commission, the Dryden High School and the Dryden Paper Company. Co-operation over the years has been excellent and these enthusiastic instructors have provided the students a first hand opportunity to meet with people who are directly concerned with managing natural resources.

Two camp administrators are appointed to look after all camp detail and to the comfort and safety of students and instructors during their 3 day stay in camp. There is a Dean of Ladies in charge of the girls attending.

There are no charges of any kind and all meals, accommodations and transportation is provided by Dryden Paper Company.

For three full days the selected students live at the Dryden Paper Company Contact Bay camp on Wabigoon Lake some 20 miles south of Dryden. During their stay, all instruction takes place in the field from 8:00 A.M. to 5:00 P.M. at prescribed sites, to accentuate the different phases of conservation. In the evening from 7:00 to 9:00 P.M. the students report on the different stops made during the day and view movies on the subject of forest, water, soil and wildlife conservation.

Stops during the field tour include a logging camp, power house, tree nursery, a nature trail for plant, tree and insect identification, beaver habitat and fish and wildlife study, provincial park, a farm, various soil profiles, gauging of stream flow, a provenance test, a forest fire protection display and a tree measurement stop.
Live-in accommodation is provided at camp for 36 students and an additional 36 students commute daily by bus from Dryden.

For many of these students this is the first prolonged time away from home. While they learn to work together they are also encouraged to compete in good housekeeping habits (boys vs girls) the writing of individual conservation slogans and producing skits for entertainment.

During the review session each evening the students are divided into groups and asked to report on what they have learned on a particular aspect of the days field tour. Any errors or omissions are then pointed out, firstly by the other students and finally by the instructor responsible for that particular subject. This review session is perhaps the key to the amount of information picked up and retained by the students. Throughout the course the instructors emphasize the inter-relation and dependence of the renewable natural resources and with this knowledge the awareness comes an understanding of the true concepts on which management is based.

To date 570 grade $X$ students have attended the conservation camp and it is hoped that the understanding gained of the importance of our natural resources, has been passed on each year to their family and friends. The course has had many interested observers from other industrial organizations and has led to the introduction of other similar courses in the Province of Ontario.

The Dryden Paper Company is concerned about the future of Ontario's natural resources and feel that a course such as this will assist in providing young people with a better understanding of the importance of wise use of their natural heritage.

\section{NOTICE}

\section{To all those holding C.I.F. Life Insurance}

As recently announced our Life Insurance Plan has been changed.

1. Ownership - You may now have a "Third-Party" such as your wife, son, daughter or another person become the owner of the policy on your life. The insurance will then be outside your Estate and this may reduce Estate Tax and/or Succession Duty, or,

The insurance may now be owned by a business partner to carry out the terms of a "buy-sell" stock or partnership agreement, or,

You may now continue to be owner of the policy for protection of your family but, now, you may have the option of assignment for business purposes such as collateral to a loan.

The OWNER must pay all premiums.

2. Increased Amount - You may now apply for Plan C which insures $\$ 40,000.00$ plus bonus, a total of $\$ 50,000.00$ at the same low scale of premiums - The $25 \%$ bonus will be added to all death claims during the present contract year up to April 30th, 1971 and beyond if good experience continues.

3. All current holders of C.I.F. Life Insurance must complete the new application card which has been mailed directly to them and they will receive a new policy containing the above privileges.

If holders of C.I.F. Life Insurance wish to increase the amount of their insurance they must also complete the health form questionnaire and send it together with a cheque or money order for proportionate premium up to May 1st 1971 on the difference.

Submit questions either to C.I.F. Office or to H. K. Hunt, C.L.U., The Imperial Life, 44 Victoria Street, Suite 508, Toronto 1. 